Pobrane z czasopisma Annales I - Philosophy and Sociology http://philosophia.annales.umcs.pl Data: 26/04/2023 01:07:36

DOI: $10.17951 /$ i.2017.42.1.107

A N N A LES

UNIVERSITATIS MARIAE CURIE-SKŁODOWSKA

LUBLIN - POLONIA

VOL. XLII, 1

SECTIO I

2017

MAŁGORZATA KOZIOŁ

Uniwersytet Marii Curie-Skłodowskiej w Lublinie

\title{
Analiza zjawiska cyberseksu jako współczesnej formy zaspokajania popędu seksualnego
}

Analysis of the Cybersex Phenomenon as a Modern Form of Satisfying Sexual Desire

Kiedy ciało jest fizycznie nieobecne, lukę po nim może wypełnić nasza wyobraźnia ${ }^{1}$.

\section{WPROWADZENIE}

Internet w swoim pierwotnym założeniu miał łączyć wyłącznie komputery, a nie - jak to się dzieje obecnie - jego użytkowników. Stworzony w 1968 r. dla celów Departamentu Obrony Stanów Zjednoczonych na wypadek wojny nuklearnej, miał służyć jako środek wymiany danych pomiędzy pracownikami. Jednak już w 1985 r. stał się popularną technologią i swoistym narzędziem wykorzystywanym przez liczną społeczność. Natomiast z początkiem lat 90. (dokładnie w 1993 r.), po pojawieniu się pierwszych ogólnodostępnych przeglądarek internetowych, rozpoczęło się publiczne tworzenie rzeczywistości wirtualnej - cyberprzestrzeni. Oprócz możliwości kreacji świata, sieć stała się dla swoich użytkowników miejscem kreacji własnej osoby ${ }^{2}$.

Jedna z definicji cyberprzestrzeni określa ją jako miejsce, w którym powstaje wirtualna rzeczywistość, wygenerowana przez program komputerowy ${ }^{3}$. Aaron

1 M.T. Whitty, A.N. Carr, Wszystko o romansie w sieci. Psychologia związków internetowych, Gdańsk 2009, s. 50.

2 Ibidem, s. 20-21.

3 Ibidem, s. 78. 
Ben-Ze'ev uważa, iż choć cyberprzestrzeń jest wspierana przez zaawansowane technologie, to ostatecznie to nie one ją definiują, lecz różne rodzaje psychicznych interakcji w niej zachodzące. Cyberprzestrzeń, nie będąc przestrzenią fizyczną, sprawia, że jej cechy, takie jak odległość i lokalizacja, według twierdzenia badacza nie są mierzone za pomocą fizycznych parametrów, tylko przez wartości psychologiczne. Zatem wirtualna przestrzeń stanowi domenę psychologiczną i społecznąa

Cechę wirtualności cyberprzestrzeni nadaje fakt, iż jej nieodłączną częścią jest wyobraźnia. Niemniej - jak zauważa Ben-Ze’ev - ta wirtualna sfera życia jednostki jest bardzo realna w innym ważnym wymiarze. Mianowicie w sieci dochodzi do interakcji, które wielokrotnie przeradzają się w związki między dwiema rzeczywistymi osobami, nie jest więc ona relacją wyimaginowaną. $Z$ tego względu według naukowca błędem jest postrzeganie cyberprzestrzeni jako przeciwieństwa przestrzeni realnej - cyberprzestrzeń jest bowiem częścią rzeczywistości ${ }^{5}$.

Konkludując, należy podkreślić, że wynalezienie, a następnie rozwój nowych technologii - szczególnie Internetu - zrewolucjonizowało życie człowieka zarówno na poziomie jednostkowym, jak i społecznym. Internet wraz ze swoją szybką ekspansją stał się ogromną zbiorową nieświadomością zapewniającą wgląd w nasze potrzeby, pragnienia i fantazje ${ }^{6}$. Coraz częściej ,poprzez albo przy użyciu” komputera i Internetu jednostka ma możliwość zaspokojenia wielu swoich potrzeb, tj. społecznych, psychicznych, biologicznych?

W opinii seksuologa Zbigniewa Lwa-Starowicza powstanie nowych rozwiązań technologicznych oraz ich intensywna, permanentna ewolucja, zrewolucjonizowało sferę komunikacji międzyludzkiej, wpływając także na erotyzm jednostki. Przemianom uległy, i wciąż ulegają, tradycyjne formy zachowań seksualnych.

Philip Robinson i Nancy Tomosaitis już w 1995 r. w przedmowie do swojej książki Cyberseks. Prężny przewodnik po erotyce elektronicznej pisali:

Dziś cyberseks istnieje w formie tekstowej i graficznej na BBSach, ,liniach pogawędek” on-line, dyskietkach i interakcyjnych dyskach CD-ROM. Ale niedługo nadejdzie ostateczne doznanie cyberseksu w „rzeczywistości wirtualnej”. Rzeczywistość wirtualna, która obiecuje między innymi doświadczenie symulowanego seksu. Związek najstarszego i najsilniejszego popędu człowieka z najbardziej wyrafinowaną i potężną nową technologią jest dążeniem, które być może już niedługo nieodwołalnie zmieni międzyludzkie stosunki seksualne ${ }^{8}$.

4 A. Ben-Ze'ev, Miłość w sieci. Internet i emocje, Poznań 2005, s. 16.

Ibidem, s. 17.

6 P.G. Zimbardo, N.S. Coulombe, Gdzie ci mężczyźni?, Warszawa 2015, s. 154.

7 K. Waszyńska, $W$ (nie)rzeczywistej relacji z innymi, czyli miłość $i$ seks w cyberprzestrzeni, „Studia Edukacyjne” 2015, nr 34, s. 197.

8 Cyt. za: P. Robinson, N. Tomosaitis, Cyberseks. Prężny przewodnik po erotyce elektronicznej, Warszawa 1995, s. 13. 
Pobrane z czasopisma Annales I - Philosophy and Sociology http://philosophia.annales.umcs.pl Data: 26/04/2023 01:07:36

Analiza zjawiska cyberseksu jako współczesnej formy zaspokajania popędu...

Wraz ze wzrostem popularności Internet stał się miejscem, w którym rozkwita ludzka seksualność, a każdego dnia zwiększa się liczba osób, które w cyberprzestrzeni zaspokajają swój popęd seksualny przez odbywanie „wirtualnych stosunków". Powyższe zjawisko, określane mianem cyberseksu, staje się nowym modelem aktywności seksualnej $\mathrm{Z}$ badań Zbigniewa Izdebskiego na temat seksualności Polaków, przeprowadzonych w 2011 r., wynika, że 49\% mężczyzn i 27\% kobiet poszukiwało w Internecie materiałów o treści erotycznej, 10\% Polaków uprawiało seks w realu z osobą poznaną w Internecie, natomiast 5\% uprawiało seks wirtualny ${ }^{10}$. Jak twierdzi psycholog społeczny Philip G. Zimbardo, winiący nowe media za jedną z przyczyn kryzysu męskości, obecnie włączając przeglądarkę internetową, otrzymujemy „szwedzki stół z podnietami”: filmy pornograficzne, zdjęcia bądź relacje na żywo ${ }^{11}$.

Badanie na temat uprawiania wirtualnego seksu przeprowadziła również Agata Leśnicka na próbie 505 osób, które zdecydowały się wypełnić internetową ankietę. Wyniki wskazały, że aż 393 respondentów przyznało się do uprawiania cyberseksu (78\%), w tym 51 kobiet i 342 mężczyzn $^{12}$.

Celem niniejszego opracowania jest próba analizy zjawiska cyberseksu, na którą składać się będą m.in. następujące elementy: definicja cyberseksu prezentowana przez poszczególnych badaczy tego zjawiska, przyczyny uprawiania tego typu aktywności oraz czynniki stanowiące o jego atrakcyjności. Oprócz tego zostaną przedstawione pejoratywne skutki uprawiania cyberseksu dla funkcjonowania psychospołecznego jednostki, jej seksualności oraz dla relacji międzyludzkich. Przeglądowy charakter pracy dodatkowo zostanie wzbogacony badaniami na temat wirtualnej intymności, realizowanymi zarówno na gruncie zagranicznym, jak i polskim.

\section{DEFINICJA CYBERSEKSU}

Wśród badaczy zjawiska cyberseksu nie ma zgodności co do jego definicji. Stanowi to podstawę do przedstawiania różnych jego ujęć przez naukowców zagranicznych i polskich.

$9 \quad$ A. Leśnicka, Cyberseks w polskim Internecie - ankieta dla uzytkowników czatów erotycznych, „Seksuologia Polska” 2009, nr 7(1), s. 143; Z. Lew-Starowicz, Encyklopedia erotyki, Warszawa 2001, s. 143.

10 Badanie Zbigniewa Izdebskiego i Polpharmy Seksualność Polaków 2011, www.termedia.pl/mz/-Badanie-Zbigniewa-Izdebskiego-i-Polpharmy-Seksualnosc-Polakow-2011-,5152.html [dostęp: 14.02.2017].

11 P. G. Zimbardo, N.S. Coulombe, op. cit., s. 154.

12 A. Leśnicka, Cyberseks w polskim Internecie..., s. 12. 
I tak, zaczynając od polskiego piśmiennictwa, cyberseks według Encyklopedii erotyki autorstwa Zbigniewa Lwa-Starowicza to:

[...] aktywność seksualna uprawiana za pomocą komputera, w której zakres wchodzą: erotyczne gry, pornografie, nawiązanie znajomości, pobudzenie drugiej osoby pośrednio lub bezpośrednio dzięki użyciu elektrod, zachowania masturbacyjne (dzięki użyciu hełmów, rękawic, nakładek, cyberpenisów, cyberkondomów, lalek komputerowych), kreowanie rzeczywistości wirtualnej ${ }^{13}$.

Nieco inaczej definicję zjawiska prezentuje izraelski filozof Aaron Ben-Ze'ev, który wirtualny seks ujmuje w dwóch aspektach. W ujęciu szerszym stwierdza, iż są to wszelkiego typu czynności związane z seksem, odbywające się w cyberprzestrzeni. Natomiast w ujęciu węższym cyberseks odnosi do:

[...] interakcji społecznej pomiędzy minimum dwiema osobami, które wymieniają przekaz cyfrowy w czasie rzeczywistym. Wiadomości przesyłane są zazwyczaj przez prywatne kanały komunikacji, takie jak poczta elektroniczna albo komunikator, ale mogą być też zamieszczone w ogólnie dostępnym czacie, wtedy można je spostrzegać jako publiczne akty seksualne ${ }^{14}$.

Dokonując głębszej analizy powyższych definicji, można zauważyć pewne „luki” informacyjne uniemożliwiające precyzyjne wyjaśnienie specyfiki omawianego zjawiska. Obaj badacze przede wszystkim skupili się na wskazaniu komputera jako środka przekazu, za pomocą którego można uprawiać wirtualną miłość, oraz na wylistowaniu czynności wykonywanych w jej ramach. Ben-Ze'ev ponadto zwrócił uwagę na konieczność obecności użytkowników wirtualnych stosunków. Żaden z przywołanych naukowców nie uwzględnił jednak celu uprawiania net-seksu.

Dokonali tego natomiast Michael W. Ross i Michael R. Kauth, według których zachowania seksualne są zachowaniami zastępczymi, stojącymi w opozycji do tych, które są realizowane w świecie rzeczywistym. Oprócz tego zawierają one rozbudowany, szczegółowy opis słowny, którym towarzyszy podniecenie seksualne prowadzące wielokrotnie do osiągnięcia orgazmu ${ }^{15}$.

$\mathrm{Na}$ cechę cyberseksu stojącą w opozycji do stosunków realnych wskazuje także Charlene Blair. Podkreśla ona, iż ze względu na fakt dokonywania aktywności seksualnej za pośrednictwem przekazu cyfrowego, sensoryczność człowieka jest ograniczona, tj. podczas aktu wirtualnego seksu na jednostkę oddziałuje mniejsza ilość zmysłów niż w trakcie seksu realnego ${ }^{16}$.

13 Z. Lew-Starowicz, op. cit., s. 143.

14 A. Ben-Ze'ev, op. cit., s. 19.

15 M. Pozdał, Cyberseks - cyberprzyjemność? Internetowa aktywność seksualna. Nowe możliwości i zagrożenia, [w:] Tabu seksuologii, red. A. Jodko, Warszawa 2008, s. 118.

16 Ibidem. 
Pobrane z czasopisma Annales I - Philosophy and Sociology http://philosophia.annales.umcs.pl Data: 26/04/2023 01:07:36

Analiza zjawiska cyberseksu jako współczesnej formy zaspokajania popędu...

Podobnie jak Ben-Ze'ev autorzy książki Wszystko o romansie w sieci. Psychologia zwiazków internetowych - Monica T. Whitty i Adrian N. Carr - w swojej definicji zjawiska komputerowego seksu wskazują na konieczność obecności dwóch lub większej liczby osób realizujących wirtualny stosunek w czasie synchronicznym. Dodatkowo zaznaczają, że strony dzielą się swoimi fantazjami seksualnymi, które podczas wirtualnych stosunków stanowią jedną z istotniejszych kwestii. Według starej prawdy $90 \%$ seksu dzieje się właśnie w głowie jednostki. Dla potwierdzenia tej tezy badacze przytaczają wypowiedzi osób uprawiających wirtualną miłość, które wielokrotne nie mogą wyjść z podziwu, z jak silnymi wiąże się to doznaniami - zarówno emocjonalnymi, jak i fizycznymi, spotęgowanymi dodatkową masturbacją jednego lub obydwu wirtualnych partnerów ${ }^{17}$.

Przytoczone wyżej definicje są dowodem na brak jednoznacznej zgody co do wytłumaczenia zjawiska cyberseksu. Niemniej na ich podstawie można wyróżnić pewne stałe elementy warunkujące zjawisko cybernetycznego seksu. Są to m.in.:

- podłączenie się do sieci www lub zalogowanie się w sieci www,

- obecność dwóch lub większej liczby osób,

- wzajemne wysyłanie materiałów o treści erotycznej w postaci opisów słownych, ustnych, dźwięków bądź obrazów (zdjęć lub filmików),

- duża rola wyobraźni, snucie fantazji erotycznych,

- masturbacja lub inne zachowania seksualne, włącznie z używaniem gadżetów erotycznych,

- cel będący osiągnięciem natychmiastowej gratyfikacji seksualnej przez daną osobę w postaci podniecenia seksualnego, często zakończonego osiągnięciem orgazmu.

Na koniec warto jeszcze scharakteryzować formy, jakie może przybierać wirtualny seks. Są to m.in.:

- pozowanie nago przed kamerą internetową,

- wysyłanie drogą internetową zdjęć, obrazów lub plików dźwiękowych o tematyce erotycznej i/lub pornograficznej,

- nagrywanie krótkich filmów erotycznych i/lub pornograficznych ze sobą $\mathrm{w}$ roli aktora i umieszczanie ich na stronach internetowych, pamiętnikach internetowych - tzw. blogach (web log - dziennik internetowy),

- masturbacja w trakcie interakcji internetowej,

- symulowanie stosunku seksualnego przez wzajemnie zsynchronizowane wysyłanie komunikatów głosowych do drugiej osoby i jednoczesną masturbację, - wykorzystywanie bardziej zaawansowanych technologii komputerowych,

17 M.T. Whitty, A.N. Carr, op. cit., s. 49. 
Pobrane z czasopisma Annales I - Philosophy and Sociology http://philosophia.annales.umcs.pl Data: 26/04/2023 01:07:36

jak np. zakładanie rękawic i hełmu, które - podłączone okablowaniem do programu komputerowego - pozwalają na realistyczną symulację gry seksualnej z wirtualnym partnerem ${ }^{18}$.

\section{CZYNNIKI WARUNKUJĄCE ATRAKCYJNOŚĆ WIRTUALNEGO SEKSU ORAZ PRZYCZYNY JEGO UPRAWIANIA}

Jak wynika z przytoczonych wcześniej badań Agaty Leśnickiej, obecnie wzrasta liczba ludzi uciekających się do specyficznej formy zaspokajania popędu seksualnego, jaką jest cyberseks ${ }^{19}$.

Katelyn Y.A. McKenna, Amie S. Green i Pamela K. Smith wysuwają tezę jakoby zwiększenie blokady ekspresji seksualnej w życiu człowieka doprowadzało do jej ujawniania w cyberprzestrzeni. Jednostka, nie mogąc wyrażać w pełni swoich potrzeb czy fantazji seksualnych w życiu codziennym, idealne wyjście dla ich ujścia i realizacji odnajduje w sieci ${ }^{20}$. Według Anthony’ego Giddensa Internet umożliwia przekształcanie seksualności przez eksperymentowanie. W cyberprzestrzeni dochodzi do oddzielenia psyche od ciała czy seksualności od cielesności. To skutecznie umożliwia jego użytkownikom podejmowanie czynności, które w świecie realnym zostałyby uznane za perwersyjne i niemoralne. Wyjaśniając słowami Krzysztofa Nowosielskiego: „Internetowa modyfikacja intymności i seksualności sprawia, że tworzy się świat, w którym to, co pisane (słowna stymulacja fantazji seksualnych w »wirtualu«) i to, co wykonywane (kontakt fizyczny w »realu«), to dwie całkowicie różne rzeczy"21.

Według Alvina Coopera wpływ na to mają trzy główne czynniki, określane „mechanizmem trzech A". Internet ośrodek komunikacji:

- dostępny (Access),

- niedrogi (Affordable),

- anonimowy (Anonymous) ${ }^{22}$.

Jeszcze kilka lat temu świat wirtualny dla wielu jednostek był poza zasięgiem w dosłownym tego słowa znaczeniu. Obecnie dostępność oraz zasięg Internetu są coraz większe, co sprawia, że człowiek w każdym czasie oraz niemal z każdego

18 D. Skowroński, M. Nowicka, Kto korzysta z seksu internetowego w Polsce?, „Seksuologia Polska" 2008, nr 6(1), s. 8.

19 A. Leśnicka, Cyberseks w polskim Internecie..., s. 12.

20 K. Waszyńska, Cybersexual addiction. Diagnostyka i leczenie, „Nowiny Lekarskie” 2011, nr 80(5), s. 368.

${ }^{21}$ K. Nowosielski, Cyberseksualność, [w:] Podstawy seksuologii, red. Z. Lew-Starowicz, V. Skrzypulec, Warszawa 2010, s. 280.

22 R. Kowalczyk, A. Budna, M. Rogowska, Seks w sieci. Korzyści i zagrożenia, „Przegląd Seksuologiczny” 2009, nr 20, s. 29. 
Pobrane z czasopisma Annales I - Philosophy and Sociology http://philosophia.annales.umcs.pl Data: 26/04/2023 01:07:36

Analiza zjawiska cyberseksu jako współczesnej formy zaspokajania popędu...

miejsca na ziemi może wejść w „imaginowany raj”, aby zaspokoić swoje potrzeby. Puentą tej sytuacji może być twierdzenie Ben-Ze’eva, że współcześnie odnalezienie partnera do wirtualnych zabaw cielesnych jest prostsze i tańsze niż w życiu realnym ${ }^{23}$.

Co więcej, wirtualny stosunek jest bezpieczniejszy od tego realnego pod względem zdrowotnym. Prawdopodobieństwo zachorowania na chorobę czy infekcję przenoszoną drogą płciową jest niemal zerowe, podobnie jak wypełnienie funkcji reprodukcyjnej (tzn. zajście przez kobietę w ciążę) $)^{24}$.

Kolejną korzyścią przebywania w sieci jest zaspokojenie oczekiwań wobec własnej osoby oraz partnera. To za sprawą wyobraźni jednostka może kreować swoją osobę zgodnie z wizją, jakiej pragnie. Tym samym dochodzi do manipulacji własnym wizerunkiem - osoba dokonuje tzw. selektywnej autoprezentacji ${ }^{25}$. Ponadto, nie znając wirtualnego partnera, zdarza się, że nawet nie wiedząc, jak wygląda, jednostka tworzy jego własny idealny obraz. Idealizacji podlega także tworzony związek, co stanowi element niezbędny w miłości romantycznej ${ }^{26}$. Dzięki wyobraźni, dokonując wirtualnego aktu seksualnego, użytkownik jest w stanie spełnić swoje fantazje dotyczące partnera, jego wyglądu czy intensywności seksualnej.

Na atrakcyjność nawet najbardziej „wyuzdanych potrzeb seksualnych” wpływa aspekt anonimowości. Dzięki takiemu poczuciu jednostka czuje się bardziej pewna i swobodna, otwarcie wyraża swoje fantazje i potrzeby ${ }^{27}$. Ponadto anonimowość świata wirtualnego przyczynia się do zniesienia wielu społecznych przekonań i stereotypów, w szczególności dotyczących kobiet. Dzięki temu kobieta chcąca spełnić swoje osobiste, specyficzne fantazje erotyczne, nie zostaje narażona na nieprzyjemne uwagi, co mogłoby mieć miejsce w rzeczywistości ${ }^{28}$. Wirtualny seks chroni ją również przed przemocą, niechcianą ciążą oraz daje możliwość bezpiecznego, kontrolowanego flirtowania. Natomiast w przypadku mężczyzn pozwala na ukrycie problemów, $\mathrm{z}$ którymi borykają się w życiu realnym, tj. problemów z erekcją, kompleksów związanych z wielkością członka czy poczuciem braku atrakcyjności fizycznej ${ }^{29}$.

Wszelkiego typu grupy dyskusyjne dotyczące danych zagadnień bądź czaty erotyczne poświęcone poszczególnym preferencjom seksualnym gromadzą ludzi

\footnotetext{
23 A. Ben-Ze'ev, op. cit., s. 35.

24 K. Nowosielski, op. cit., s. 279.

25 R. Kowalczyk, A. Budna, M. Rogowska, op. cit., s. 29.

26 A. Ben-Ze'ev, op. cit., s. 35

27 D. Skowroński, M. Nowicka, op. cit., s. 7.

28 K. Waszyńska, Cybersexual addiction..., s. 368.

29 K. Nowosielski, op. cit., s. 281.
} 
Pobrane z czasopisma Annales I - Philosophy and Sociology http://philosophia.annales.umcs.pl Data: 26/04/2023 01:07:36

o podobnych zainteresowaniach i upodobaniach. To - w połączeniu ze zwiększoną ekspresją w wyrażaniu swoich myśli - przyczynia się do łatwiejszego i szybszego odnalezienia się oraz nawiązania kontaktu ${ }^{30}$.

Opcja zaspokajania popędu seksualnego w świecie wirtualnym dla wielu jednostek jest wartościowa i częściej wybierana ze względu na brak możliwości bezpośredniej oceny wirtualnego kochanka. Osoba ukrywająca się pod nickiem nie może być oceniona np. pod względem wyglądu, ponieważ go nie ujawnia. Stąd można wysnuć wniosek, iż częstymi użytkownikami chat rooms są osoby uważające się za mało atrakcyjne i niekoniecznie zdolne do nawiązania relacji w świecie realnym.

Internet pozwala swoim użytkownikom oderwać się od świata prawdziwych problemów i trosk życia codziennego. Sieć pozwala ludziom na wyrażanie swoich prawdziwych emocji i rozładowanie stresu. Tezę tę potwierdzają wyniki badań Marii Chuchry, która w swoich badaniach nad zależnościami zachodzącymi między wybranymi formami aktywności młodzieży w Internecie a występowaniem konfliktów z rodzicami, doznawaniem przemocy psychicznej z ich strony oraz uzależnieniem od alkoholu członka rodziny, otrzymała wynik mówiący, iż uzależnienie członka rodziny współwystępuje z uprawianiem wirtualnego seksu $^{31}$.

Ponadto seks przez Internet zmniejsza ryzyko zranienia i minimalizuje znaczenie norm społecznych. Oprócz tego stanowi on atrakcyjną opcję dla osób o niskim poczuciu własnej wartości. Jednostki nieśmiałe oraz przejawiające trudności w kontaktach społecznych w tego typu aktywności upatrują wartości terapeutycznych ${ }^{32}$.

Dariusz Skowroński i Marika Nowicka w swoich badaniach dotyczących osób korzystających z komputerowego seksu dokonali także jakościowej analizy motywów zaspokajania potrzeb intymnych w świecie wirtualnym. Na podstawie uzyskanych wyników można wskazać, że respondenci jako główne powody swej aktywności podawali:

- chęć rozładowania napięć seksualnych,

- nieobecność/brak partnera,

- ciekawość,

- chęć zobaczenia nowości, znalezienia inspiracji,

- chęć obejrzenia filmów pornograficznych,

30 A. Leśnicka, Zjawisko cyberseksu z perspektywy psychologii społecznej, „Przegląd Seksuologiczny" 2011, nr 27, s. 11.

31 M. Chuchra, Wybrane symptomy dysfunkcjonalności rodziny a aktywność studentów w Internecie, „Curr. Probl. Psychiatry” 2014, nr 15(2), s. 76.

32 D. Skowroński, M. Nowicka, op. cit., s. 7-8. 
Pobrane z czasopisma Annales I - Philosophy and Sociology http://philosophia.annales.umcs.pl Data: 26/04/2023 01:07:36

Analiza zjawiska cyberseksu jako współczesnej formy zaspokajania popędu... 115

$$
\begin{aligned}
& \text { - „bo jest darmowy”, } \\
& \text { - „bo lubię”, } \\
& \text { - „Z nudów”33. }
\end{aligned}
$$

\section{NEGATYWNE OBLICZE CYBERSEKSU}

Krzysztof Nowosielski w artykule na temat cyberseksualności we wstępie przestrzega, że Internet jako potężne źródło informacji z pozytywnego wynalazku może przekształcić się w czynnik ingerujący w prywatność, zmieniający relacje interpersonalne oraz wpływający na ludzką seksualność. Szczególnym zagrożeniem jest on dla jednostek młodych, niedojrzałych emocjonalnie ${ }^{34}$. Wielokrotnie walory komputerowego seksu sprawiają, iż użytkownicy nie są świadomi negatywnych konsekwencji tej „przyjemnej” aktywności. Ta pozornie niewinna zabawa może się przerodzić w uzależnienie, z którym zerwanie wymaga psychoterapii.

Niejednokrotnie dochodzi do sytuacji, w których cechy cyberseksu - uważane za pozytywne oraz podnoszące atrakcyjność - w efekcie stają się wrogie wobec użytkownika. Za przykład może posłużyć aspekt anonimowości. Jej poczucie wiele razy okazuje się złudne, a idealny wirtualny partner przeobraża się w prześladowcę. Ta sytuacja może doprowadzić nawet do pojawienia się u jednostki swoistych lęków prześladowczych ${ }^{35}$. Cyberseks może ponadto wzmacniać zachowania dewiacyjne jednostki, dla której wirtualna przestrzeń stanowi miejsce na odnalezienie innych osób, które zaspokoją jej potrzeby. Internet pozwala również na „bezpieczne” poszukiwanie swoich ofiar przez przestępców seksualnych ${ }^{36}$.

Komputerowy seks przyczynia się do spłycenia bądź nawet spadku wartości i atrakcyjności stosunków realnych. W ostateczności może dojść do sytuacji, w której osoba zaspokajająca swój popęd seksualny w sieci w niej też „zamyka” swoją seksualność. Doprowadza to do takiej sytuacji, gdzie jednostka przestaje widzieć sens w prawdziwych stosunkach oraz doświadczać satysfakcji z ich uprawiania ${ }^{37}$. Opisana sytuacja jest szczególnie groźna dla osób młodych, które nie miały okazji doznać doświadczeń seksualnych, a ich inicjacja seksualna w pewien sposób „dokonała się w sieci”. Prawo pierwszych połączeń przyczynia się do wyzwolenia najsilniejszych emocji i skojarzeń, tym samym wywierając niezwykle istotny wpływ na dalsze funkcjonowanie człowieka. W kontekście cyberseksu, który - jak już zostało zaznaczone - stanowi pewną formę inicjacji seksualnej dla młodzieży,

\footnotetext{
33 Ibidem, s. 10.

34 K. Nowosielski, op. cit., s. 277.

35 M.T. Whitty, A.N. Carr, op. cit., s. 147.

36 K. Nowosielski, op. cit., s. 283.

37 R. Kowalczyk, A. Budna, M. Rogowska, op. cit., s. 31-32.
} 
Pobrane z czasopisma Annales I - Philosophy and Sociology http://philosophia.annales.umcs.pl Data: 26/04/2023 01:07:36

nastolatek przeżywa bardzo silne doświadczenia seksualne w oderwaniu od emocjonalnej więzi z drugą osobą. Ten egocentryczny schemat zachowań seksualnych powoduje, że młodzi ludzie uczą się powierzchownego i płytkiego spojrzenia na kontakt seksualny oraz przedmiotowego traktowania przyszłych partnerów, potrzebnych wyłącznie do zaspokojenia popędu seksualnego ${ }^{38}$.

Co więcej, negatywne skutki cyberseksu stanowią swoiste zagrożenie dla związku, jego trwałości i pozytywnych relacji między partnerami. Niejednokrotnie jest on powodem kłótni, a nawet rozpadu małżeństwa - co trzeci rozwód w USA jest spowodowany odkryciem zdrady partnera w Internecie ${ }^{39}$. Jak zaznacza Mirosława Ściupider-Młodkowska:

[...] wirtualny stosunek [...] obnaża intymność partnerską z jej naturalnych doznań, a obcowanie z maszyną, wirtualnością, obcym partnerem, z którym wchodzi się w intymny akt seksualny, pogłębia jedynie pustkę i samotność ludzi. Sieciowe relacje, nie tylko te o charakterze erotycznym, doprowadzają do izolacji jednostki oraz stają się przyczyną coraz częstszych zaburzeń w osobowości ${ }^{40}$.

Autorka w omawianym zjawisku upatruje także zagrożeń wynikających z braku bezpośredniego kontaktu użytkowników. „Poznając” swojego wirtualnego partnera na podstawie tekstu czy fotografii, jednostka buduje jego obraz za pomocą swojej wyobraźni. Ta wyobraźnia internetowa wyzwala w niej fantazję opartą wyłącznie na wyobrażeniu, a nie na prawdziwej zmysłowości potrzebnej do budowania i rozwoju uczucia czy intymnych i długotrwałych relacji ${ }^{41}$. Dodatkowo przedmiotowy charakter relacji może doprowadzić do przekonania, że budowanie związków w świecie realnym - w porównaniu z seksem w sieci - jest zbyt czasochłonne, a związek małżeński jest zbyt banalny, nieatrakcyjny, a nawet nudny, ponieważ nie dostarcza tylu nowych doznań i ekscytacji42.

Należy również mieć na uwadze, iż z czasem stymulacja dostarczana przez cyberseks powszednieje. Dochodzi bowiem do sytuacji, w których wraz ze zwiększonym angażowaniem się w wirtualny seks rośnie też potrzeba utrzymania poprzedniego podniecenia. Ponadto niejednokrotnie jednostka, zachęcona zwiększoną możliwością próbowania nowych rzeczy w anonimowej rzeczywistości online, przenosi coraz bardziej dewiacyjne praktyki do życia codziennego ${ }^{43}$.

38 I. Ulfik-Jaworska, W pułapce wirtualnego seksu Iwona, http://rodzina.opoka.org.pl/dwaplus/trud/6899.0,W_pulapce_wirtualnego_seksu.prn [dostęp: 16.02.2017].

39 K. Nowosielski, op. cit., s. 288.

40 M. Ściupider-Młodkowska, Intymność w kulturze flirtu i uwodzenia. Czywirtu@lny seks na zawsze odmieni intymne relacje partnerskie?, „Studia Edukacyjne” 2013, nr 29, s. 320.

41 Ibidem.

42 I. Ulfik-Jaworska, op. cit.

43 A. Leśnicka, Cyberseks w polskim Internecie..., s. 11. 
Pobrane z czasopisma Annales I - Philosophy and Sociology http://philosophia.annales.umcs.pl Data: 26/04/2023 01:07:36

Analiza zjawiska cyberseksu jako współczesnej formy zaspokajania popędu...

Obecnie obserwuje się stały wzrost populacji osób uprawiających komputerowy seks przy jednoczesnym pozostawaniu w związkach poza cyberprzestrzenią. I chociaż $70 \%$ internautów mających stałego partnera w rzeczywistości cyberseks rozpatruje w kategoriach zdrady, to aż $87 \%$ nie odczuwa poczucia winy związanego z niewiernością ${ }^{44}$. Ten brak poczucia winy często jest tłumaczony faktem braku fizycznego zbliżenia. Zwolennicy traktowania wirtualnego seksu jako formy zdrady uważają, że w wielu przypadkach, w efekcie wirtualnych stosunków, z czasem może dojść do zaangażowania emocjonalnego stron ${ }^{45}$. Powyższe stwierdzenia potwierdzają badania, które wykazały, iż zdrada nie jest powiązana wyłącznie z kontaktem fizycznym. Już sama wymiana emocji jest wystarczającym powodem, zwłaszcza dla kobiet, aby traktować cyberflirt jako niewierność partnera ${ }^{46}$.

Oprócz tego aktywność seksualna w Internecie powoduje u użytkowników trudności w podejmowaniu decyzji co do zaangażowania się w jedną znajomość. Przede wszystkim wynika to z mnogości ofert, które zawsze mogą okazać się bardziej atrakcyjne i znajdują się „,na wyciągnięcie ręki”. Zjawisko cyberseksu idealnie wpisuje się w obecną kulturę instant, której priorytetem jest natychmiastowe osiągnięcie celu. Akceleracji ulega też sfera emocji jednostki, która uzyskuje natychmiastowy efekt zaspokojenia potrzeb. W wyniku instrumentalizacji życia następuje silne akcentowanie sfery seksualnej i erotycznych zachowań jednostki, niejednokrotnie bardzo ryzykownych i konsumpcyjnych ${ }^{47}$. Dodatkowo pejoratywnym skutkiem kultury natychmiastowości jest proces oddalania się jednostek od wszelkich instytucji, w tym rodziny ${ }^{48}$.

Według Agnieszki Gromkowskiej-Melosik cybernetyczne stosunki można rozpatrywać w kategoriach ujścia dla panicznego lęku przed bliskością i autentycznością związku z żywym człowiekiem, za którego w życiu realnym trzeba brać odpowiedzialność 49 .

W wirtualnych kontaktach międzyludzkich można dopatrywać się pewnej sprzeczności, bowiem - jak zauważa socjolog Zygmunt Bauman - wirtualna bliskość oddala i dystansuje zamiast przybliżać. Co więcej, pobudza wyobraźnię kosztem konkretnych działań. Skutkiem tego wiele osób może przeżywać poważne problemy w kontaktach realnych, spowodowane brakiem umiejętności komunikacyjnych i emocjonalnych. Dlatego, jak uważa badacz, w przyszłości obserwowalne

44 K. Nowosielski, op. cit., s. 287-288.

45 R. Kowalczyk, A. Budna, M. Rogowska, op. cit., s. 31.

46 K. Nowosielski, op. cit., s. 288.

47 M. Ściupider-Młodkowska, op. cit., s. 313-314.

48 A. Zwoliński, Uzależnienie „ekranowe” jako wspótczesne zagrożenie dla rodziny, „Labor et Educatio" 2014, nr 2, s. 262.

49 M. Ściupider-Młodkowska, op. cit., s. 320. 
Pobrane z czasopisma Annales I - Philosophy and Sociology http://philosophia.annales.umcs.pl Data: 26/04/2023 01:07:36

118 Małgorzata Kozioł

będzie coraz częstsze zjawisko jednostek „,samotnych jednocześnie pozostających w nieustannym kontakcie" ${ }^{50}$. Cyberseks w tym wypadku jest i będzie nadal protezą intymnych spotkań i doświadczeń ${ }^{51}$.

Omawiając zagrożenia płynące ze zjawiska cyberseksu, należy zaznaczyć jego finalny skutek, czyli uzależnienie się od wirtualnego zaspokajania popędu seksualnego. Choć nie ma jeszcze dokładnych danych na temat wielkości populacji osób uzależnionych, szacuje się, iż ich liczba waha się między 6 a 8\%. Uzależnienie od cybernetycznego seksu można utożsamiać z definicją uzależnienia od seksu (za Carnes), które jest uważane za każde zachowanie kompulsywne o charakterze seksualnym, które zaburza prawidłowe funkcjonowanie i może się utrwalićs ${ }^{52}$. Ostatecznie dochodzi do sytuacji, w której zachowania seksualne zaczynają przybierać formę zrytualizowaną, bez której osiąganie stanów podniecenia jest coraz trudniejsze. Owe zachowania stają się natręctwami, od których jednostka nie może się uwolnić, czując przymus ich wykonywania. Do konsekwencji uzależnienia od internetowego seksu można zaliczyć m.in.: konflikty w związku, spłycenie realnych doznań seksualnych, zaburzenia emocji i uczuć czy utrwalenie postaw egocentrycznych. Co więcej, cyberseks może przyczynić się do zaburzeń tożsamościowych, ograniczyć zainteresowania i procesy logicznego myślenia u jednostki oraz stać się podłożem konfliktów z rodziną i przyjaciółmi ${ }^{53}$.

Na koniec rozważań warto zaznaczyć, że niektórzy badacze zjawiska wirtualnego seksu wskazują również na jego pozytywne strony. Jednak w opinii Andrzeja Zwolińskiego twierdzenie, że uczestnicy cybernetycznego seksu otrzymują w jego ramach wymierne korzyści, jak choćby możliwość realizacji swoich ukrytych fantazji seksualnych, jest swoistym nadużyciem. Dla poparcia swoich tez autor przywołuje badania TNS OBOP zrealizowane w 2005 r., w których aż 97\% badanych osób zadeklarowało, że wirtualny seks nie może być równie satysfakcjonujący, jak seks z realnym partnerem ${ }^{54}$.

W niniejszym artykule kwestie pozytywnego oddziaływania komputerowego seksu na jednostkę oraz rozważania nad ich zasadnością w znacznym stopniu zostały pominięte świadomie. Stanowią one bowiem tematykę, której należy poświęcić odrębne opracowanie.

\footnotetext{
$50 \quad$ Ibidem, s. 316.

51 A. Zwoliński, op. cit., s. 259.

52 K. Nowosielski, op. cit., s. 289-290.

53 Ibidem.

54 A. Zwoliński, op. cit., s. 258-259.
} 
Pobrane z czasopisma Annales I - Philosophy and Sociology http://philosophia.annales.umcs.pl Data: 26/04/2023 01:07:36

Analiza zjawiska cyberseksu jako współczesnej formy zaspokajania popędu... 119

\section{ZAKOŃCZENIE}

Tematy związane z seksualnością człowieka przez wieki były uznawane jako tabu, przemilczane, a nawet potępiane. $Z$ tego powodu nie były podejmowane jakiekolwiek publiczne dywagacje na temat sfery płciowości człowieka. Wpłynęło to na brak wiedzy na temat potrzeb seksualnych kobiety i mężczyzny. Nieznany był także temat regulacji poczęć i cyklu płciowego kobiety, co z punktu społeczno-demograficznego stanowiło rzecz nader istotną ${ }^{55}$.

Wraz z nadejściem XX w., a następnie XXI w., zmianie uległo wiele sfer życia społecznego i indywidualnego. Za sprawą szybkiego rozwoju naukowego, społecznego i ekonomicznego przemianom uległa również seksualność człowieka. Rewolucja seksualna doprowadziła do obalenia tabu seksualności, ostatecznie czyniąc sferę intymną człowieka sferą publiczną. W jej wyniku dokonał się też proces erotyzacji kultury masowej, prowadzący do powstania „kultury negliżu”. Wpływ na te zmiany mają przede wszystkim media oraz ich nieograniczona dostępnośść ${ }^{56}$.

Co więcej, doszło do desublimacji seksu, wyrażającej się w całkowitym urealnieniu wszystkich zachowań, emocji i postaw, jakie się z nim wiążą. Skutkiem tego jest uczynienie z intymnej sfery życia ludzkiego takiego samego „produktu”, jakim jest żywność, odzież, aktywność sportowa, polityka, praca zawodowa itp. ${ }^{57}$

Jak zostało zaznaczone na wstępie niniejszego artykułu, powstanie nowych rozwiązań technologicznych oraz ich intensywna, permanentna ewolucja wpłynęło na zrewolucjonizowanie tradycyjnych form zachowań seksualnych. W efekcie powstało wiele zjawisk będących ,alternatywą" dla zaspokajania popędu seksualnego, np. zjawisko cyberseksu, analizy którego dokonano w niniejszym tekście.

Dokonanie obiektywnej oceny wirtualnego seksu jest rzeczą trudną. Ta problematyka w dalszym ciągu wywołuje wiele kontrowersji, przede wszystkim w kwestii uznania komputerowego stosunku za akt seksualny. Zwolennicy uznawania cyberseksu za realny stosunek swoje stanowisko tłumaczą tym, iż seks w sieci ma charakter sensoryczny, a w jego ostatecznym celu, tak jak w rzeczywistości, dochodzi do zaspokojenia popędu seksualnego i niejednokrotnie orgazmu. Przeciwnicy natomiast jako główny argument podają fakt braku kontaktu fizycznego, będącego podstawą we współżyciu w realu.

Powyższa dyskusja nie zmienia jednak faktu, iż problem nienaturalnego zaspokajania popędu staje się zjawiskiem globalnym. Według badania agencji

55 J. Pacewicz-Biegańska, Przemiany seksualności nastolatków, „Przegląd Pedagogiczny” 2013, nr 2, s. 109.

56 Ibidem, s. 109-110.

57 A. Trela, Seksualność kobiet niepetnosprawnych-aspekty kultury i sztuki, „Hygeia Public Health" 2014, nr 49(4), s. 721. 
Nielsena z 2006 r. z 322 mln ludzi korzystających z Internetu w sposób aktywny aż około $20 \mathrm{mln}(6 \%)$ wymagało interwencji w związku z kompulsywnym zachowaniem seksualnym w sieci.

Mając na uwadze te statystyki, można stwierdzić, że żyjemy w czasach, w których potrzeby człowieka są zaspokajane w sposób mechaniczny - przez maszynę, która chroni go i o niego dba. Andrzej Zwoliński w swoim artykule na temat uzależnienia od „ekranu” pisze, iż (za Erichem Frommem):

[...] człowiek cybernetyczny ma skłonność do zachowania się w sposób zrutynizowany, stereotypowy, pozbawiony spontaniczności. Jego cechą jest m.in. brak rozróżnienia między materią martwą a żywą, niechęć do nawiązywania trwalszych związków z innymi ludźmi, używanie języka bardziej dla manipulacji niż komunikacji ${ }^{58}$.

Badania nad omawianym zjawiskiem wymagają jeszcze wielu analiz i obserwacji, ponieważ sieć permanentnie przeobraża rzeczywistość, co tworzy nowe podejście do seksualności i intymności. $Z$ tego powodu nikt nie jest w stanie przewidzieć jej dalszego rozwoju ${ }^{59}$. Niemniej niepodważalną prawdą jest, że „lepiej zapobiegać, niż leczyć".

\section{BIBLIOGR AFIA}

Badanie Zbigniewa Izdebskiego i Polpharmy Seksualność Polaków 2011, www.termedia.pl/mz/Badanie-Zbigniewa-Izdebskiego-i-Polpharmy-Seksualnosc-Polakow-2011-,5152.html [dostęp: 14.02.2017].

Ben-Ze'ev A., Miłość w sieci. Internet i emocje, Poznań 2005.

Chuchra M., Wybrane symptomy dysfunkcjonalności rodziny a aktywność studentów w Internecie, „Curr. Probl. Psychiatry” 2014, nr 15(2).

Kowalczyk R., Budna A., Rogowska M., Seks w sieci. Korzyści i zagrożenia, „Przegląd Seksuologiczny" 2009, nr 20.

Leśnicka A., Cyberseks w polskim Internecie - ankieta dla użytkowników czatów erotycznych, „Seksuologia Polska” 2009, nr 7(1).

Leśnicka A., Zjawisko cyberseksu z perspektywy psychologii społecznej, „Przegląd Seksuologiczny” 2011, nr 27.

Lew-Starowicz Z., Encyklopedia erotyki, Warszawa 2001.

Nowosielski K., Cyberseksualność, [w:] Podstawy seksuologii, red. Z. Lew-Starowicz, V. Skrzypulec, Warszawa 2010.

Pacewicz-Biegańska J., Przemiany seksualności nastolatków, „Przegląd Pedagogiczny” 2013, nr 2. Pozdał M., Cyberseks - cyberprzyjemność? Internetowa aktywność seksualna. Nowe możliwości i zagrożenia, [w:] Tabu seksuologii, red. A. Jodko, Warszawa 2008.

Robinson P., Tomosaitis N., Cyberseks. Prężny przewodnik po erotyce elektronicznej, Warszawa 1995. Skowroński D., Nowicka M., Kto korzysta z seksu internetowego w Polsce?, „Seksuologia Polska” 2008, nr 6(1).

58 A. Zwoliński, op. cit., s. 257, 261-262.

59 K. Nowosielski, op. cit., s. 279. 
Ściupider-Młodkowska M., Intymnośćw kulturze flirtu i uwodzenia.Czywirtu@lnyseksna zawsze odmieni intymne relacje partnerskie?, „Studia Edukacyjne” 2013, nr 29.

Trela A., Seksualność kobiet niepetnosprawnych - aspekty kultury i sztuki, „Hygeia Public Health” 2014, nr 49(4).

Ulfik-Jaworska I., W pułapce wirtualnego seksu Iwona, http://rodzina.opoka.org.pl/dwaplus/trud/6899.0,W_pulapce_wirtualnego_seksu.prn [dostęp: 16.02.2017].

Waszyńska K., Cybersexual addiction. Diagnostyka i leczenie, „Nowiny Lekarskie” 2011, nr 80(5). Waszyńska K., $W$ (nie)rzeczywistej relacji z innymi, czyli miłość $i$ seks $w$ cyberprzestrzeni, „Studia Edukacyjne" 2015, nr 34.

Whitty M.T., Carr A.N., Wszystko o romansie w sieci. Psychologia zwiazków internetowych, Gdańsk 2009.

Zimbardo P.G., Coulombe N.S., Gdzie ci mężczyźni?, Warszawa 2015.

Zwoliński A., Uzależnienie „ekranowe” jako współczesne zagrożenie dla rodziny, „Labor et Educatio" 2014, nr 2.

\section{SUMMARY}

The aim of the this article is the analysis of the cybersex phenomena which is being more and more frequently chosen as the "alternative" form of satisfying sexual desire. The review character of my abstract caused a deep and profound research. The contained content bases on conclusions and research of scientists carried out not only abroad, but also in Poland. The process of creating the objective assessment of cybersex and drawing constructive conclusions is very hard. Nevertheless, it is possible to state that cybersex causes numerous negative consequences such as: decrease of relationship intimacy, developing emotional emptiness, loneliness and addiction. Despite the fact that Internet gives a possibility to keep in regular contact and the virtual sex satisfies the desire, it will never replace real relations and emotions experienced in the real life. In cybersex case, I could say by paraphrasing words of Andrzej Zwoliński, cybersex is and it will still remain only the replacement of intimate encounters and experiences.

Keywords: cybersex; sexual desire; Internet; virtual space

\section{STRESZCZENIE}

Celem niniejszego artykułu jest analiza zjawiska cyberseksu, będącego coraz częściej wybieraną ,,alternatywą" zaspokajania popędu seksualnego. Przeglądowy charakter pozwolił poddać omawiane zjawisko wnikliwej analizie. Opracowanie opiera się na wnioskach i badaniach naukowców, realizowanych zarówno na gruncie zagranicznym, jak i polskim. Dokonanie obiektywnej oceny wirtualnego seksu oraz wyciągnięcie konstruktywnych wniosków jest rzeczą trudną. Niemniej można postawić tezę, że internetowy seks powoduje wiele pejoratywnych konsekwencji, takich jak: obniżenie się intymności partnerskiej, pogłębiająca się pustka i samotność ludzi oraz uzależnienie. Mimo że Internet daje możliwość stałego kontaktu, a wirtualny stosunek zaspokaja popęd seksualny, nigdy nie zastąpi on realnych relacji i prawdziwych emocji przeżywanych w życiu rzeczywistym. W przypadku cyberseksu, parafrazując słowa Andrzeja Zwolińskiego, jest i będzie on nadal jedynie protezą intymnych spotkań i doświadczeń.

Słowa kluczowe: cyberseks; popęd seksualny; Internet; przestrzeń wirtualna 
Pobrane z czasopisma Annales I - Philosophy and Sociology http://philosophia.annales.umcs.pl Data: 26/04/2023 01:07:36 